Research article

\title{
Trump, memes and the Alt-right: Emotive and affective criticism and praise
}

\author{
Lyndon C.S. WAY \\ University of Liverpool \\ Liverpool, $U K$
}

\begin{abstract}
Internet memes are the most pervasive and malleable form of digital popular culture (Wiggins 2019: vii). They are a way 'a society expresses and thinks of itself' (Denisova 2019: 2) used 'for the purpose of satire, parody, critique ...to posit an argument' (Wiggins 2019, see also Ponton 2021, this issue). The acts of viewing, creating, sharing and commenting on memes that criticise or 'troll' authority figures have become 'central to our political processes... becom[ing] one of the most important forms of political participation and activism today' (Merrin 2019: 201). However, memes do not communicate to us in logical arguments, but emotionally and affectively through short quips and images that entertain. Memes are 'part of a new politics of affectivity, identification, emotion and humour' (Merrin 2019: 222). In this paper, we examine not only what politics memes communicate to us, but how this is done. We analyse memes, some in mainstream social media circulation, that praise and criticise the authoritarian tendencies of former US President Donald Trump, taken from 4Chan, a home of many alt-right ideas. Through a Multimodal Critical Discourse Studies approach, we demonstrate how images and lexical choices in memes do not communicate to us in logical, well-structured arguments, but lean on affective and emotional discourses of racism, nationalism and power. As such, though memes have the potential to emotionally engage with their intended audiences, this is done at the expense of communicating nuanced and detailed information on political players and issues. This works against the ideal of a public sphere where debate and discussion inform political decisions in a population, essential pillars of a democratic society (Habermas 1991).
\end{abstract}

Keywords: Multimodal Critical Discourse Studies, criticisms, praise, memes, affect

For citation:

Way, Lyndon C.S. 2021. Trump, memes and the Alt-right: Emotive and affective criticism and praise. Russian Journal of Linguistics 25 (3). 789-809. https://doi.org/10.22363/2687-00882021-25-3-789-809

Научная статья

\section{Трамп, мемы и альтернативные правые: эмоциональная критика и похвала Линдон К.С. УЭЙ \\ Ливерпульский университет Ливерпуль, Великобритания}

\section{Аннотация}

Интернет-мемы - самая распространенная и гибкая форма цифровой поп-культуры (Wiggins 2019). Это способ, которым «общество выражает себя и думает о себе» (Denisova 2019: 2), используемый для сатиры, пародии, критики, для выдвижения аргумента (Wiggins 2019, 
Ponton 2021 и др.). Акты просмотра, создания, обмена и комментирования мемов, которые критикуют или «троллят» авторитетных деятелей, занимают ключевую позицию в современных политических процессах, превратились в одну из наиболее важных форм политического участия и активности (Merrin 2019: 201). Однако мемы несут информацию не через логические аргументы, а эмоционально и аффективно с помощью коротких шуток и забавных изображений. Мемы являются частью новой политики идентификации, аффективности, эмоций и юмора (Merrin 2019: 222). В данной статье исследуется не только то, что политические мемы передают, но и как они это делают. В ней анализируются мемы, широко распространенные в социальных сетях, которые восхваляют и критикуют авторитарные тенденции бывшего президента США Дональда Трампа, взятые на сайте 4Chan, продвигающего идеи альтернативных правых. Через мультимодальный подход к критическому дискурс-анализу показано, как дискурсы расизма, национализма и власти строятся при помощи мультимодальных средств эмоциональности, а не при помощи логических и хорошо структурированных аргументов. Отмечается, что, хотя мемы обладают потенциалом эмоционального взаимодействия с целевой аудиторией, это взаимодействие достигается через коммуникативные нюансы и передачу подробной информации о политических игроках. Это противоречит идеалу публичной сферы, в которой дебаты и дискуссии определяют политические решения населения и являются основой демократического общества (Habermas 1991).

Ключевые слова: мультимодальные исследования критического дискурса, критика, похвала, мемы, эмочии

\section{Для цитирования:}

Way L.C.S. Trump, memes and the Alt-right: Emotive and affective criticism and praise. Russian Journal of Linguistics. 2021. Vol. 25. № 3. P. 789-809. https://doi.org/10.22363/26870088-2021-25-3-789-809

\section{Introduction}

Since the Paleolithic Era when humans dwelt in caves, still imagery has been an integral part of how we communicate (Clottes 2019). Thousands of years later, modern media such as newspapers depend on images. These are 'instrumental in making meaning' based on a deep-seated societal belief that 'the sense of a technical, dispassionate point of view afforded by the camera continues to be central to journalistic authority' (Allbeson \& Allan 2019: 70-71). Despite our historical love of still imagery, nothing compares in volume to the daily deluge of images we now experience online. It is estimated we took over 1.2 trillion photographs in 2017 and we share more than 3 billion images every day (Lavoie 2018). Memes are an integral part of our social media engagement with imagery.

On social media, though we view 'hard' news and political commentary, studies show we prefer entertainment that communicates to us affectively as well as cognitively (Boyd 2008). This notion is not lost on political communication scholars, many of whom 'acknowledg[e] that the historical separation of entertainment and news is obsolete...' (Esralew \& Young 2012: 338). Social media users engage in 'scroll culture', where we are guided by our thumbs, skimming, reading, liking and commenting on a constant flow of artefacts that entertain and inform. Though much of this is considered 'mundane', on closer examination it is highly ideological (Way 2021a, 2021b). It is precisely through (digital) popular culture where we most experience politics 'as fun, as style, and simply as part of the taken for granted everyday world... [though these] are infused by and shaped 
by, power relations and ideologies' (Machin 2013: 347). Using the case study of memes about former US President Donald Trump, this paper considers what politics memes offer us and how these communicate to us emotionally and affectively in our insatiable search to be informed and entertained.

\section{Memes, politics and affect}

The term 'meme', coined by biologist Richard Dawkins (1976), refers to the way we pass on 'cultural information and ideas between individuals and generations', similar to the way genes are passed on between generations. However, this concept is inadequate when considering internet memes (hereafter 'memes'). It is better to consider memes as remixes and iterations, viral texts that mutate and replicate and are readily transformed and altered by purposeful human agency, with mutation being desirable and often unavoidable (Denisova 2019, Wiggins 2019).

Memes entertain us, though they are more than just a laugh. They are a way 'a society expresses and thinks of itself', where "'everyday" media texts intertwine with public discourses' (Milner 2012: 9; Denisova 2019: 2). Throughout the 1990s2000 s, memes went from an entertaining 'geek' culture in-joke to a mainstream gimmick and 'the means of political and social deliberation' (Denisova 2019: 10). They are manipulated texts produced and distributed 'for the purpose of satire, parody, critique... to posit an argument, visually, in order to commence, extend, counter, or influence a discourse' (Wiggins 2019: 11). Memes are an integral part of 'trolling culture', as defined by Merrin (2019). Here, we are not referring to 'splenetic attacks... whose hate speech, and rape and death threats... are ruining the internet [because] their abuse and hatred are serious' (Merrin 2019: 202). Much of this behaviour has been chastised as an 'anti-social personality disorder' (Bishop 2013) used by those who take advantage of 'toxic disinhibition' of anonymous, online communication to express their anger (Suler 2005: 184). Instead, this paper considers trolling more broadly, based on the fishing term to drag a 'baited line behind a boat to see what could be caught' (Merrin 2019: 202). In this sense, memes are a part of a 'sport' that ridicules 'those who get above themselves, or set themselves above others - at those asserting, or in, authority' (Merrin 2019: 202). This activity is 'central to our political processes, spreading through the mainstream to become one of the most important forms of political participation and activism today, employed by politicians, political commentators and the public alike' (Merrin 2019: 201).

Memes influence viewers' awareness of people, issues and events and connect mainstream media topics with social media users. This is evident in the 2016 US election campaign, when memes 'highlighted and promoted the trending discourses around both candidates' (Denisova 2019: 186). They are effective because they are short, snappy, entertaining and express a particular point of view through humour. They serve as 'mind-bombs', a term coined and practiced by Greenpeace cofounder Bob Hunter, by distributing a symbolic text that expresses an idea in a nutshell and has an emotional impact (Weyler 2020). When used strategically, they 
'help attract attention to political issues and suggest alternative interpretations' (Denisova 2019: 195). They are a way to understand and question concepts, identities and claims made by various political groups.

Despite the power ascribed to memes by some scholars, their limits are also recognised. Their political power lie in their ability to address and appeal to specific groups of political actors with particular views in society. In other words, memes tend to 'appeal to an already-existing attitude, assumption, prejudice, fear, point of pride, conspiracy theory, value etc. to achieve salience in a given group' (Wiggins 2019: 64). Phillips (2009) demonstrates this through his examination of the Obama Joker meme. Here, he finds this meme was used and manipulated by various groups to express a number of sometimes opposing political views. The political potential of memes are partly determined through acceptance by and incorporation into a group or community and this is limited, dependent on offline social relations and activities including people talking about and discussing memes (Wiggins 2019). Their power is also dependent on whether or not audiences indeed read memes as their producers want from a 'preferred reading position'. Furthermore, their power lies in whether audiences are able to successfully reference real-world events represented in the meme, as well as the media texts and formats memes copy, parody and/ or manipulate.

A dominant characteristic of memes is they do not communicate to us in logical well-structured arguments, but emotionally and affectively (Denisova 2019, Merrin 2019, Wiggins 2019, Way 2021a). Though both concepts are intricately linked, affect is not emotion, but 'provides and amplifies intensity [of emotion] by increasing our awareness of a certain mind or body state that we, as adults, learn to label as a particular feeling and express as a given emotion' (Papacharissi 2015: 309). So, affect, in short, is the intensity in which we experience emotion. By communicating to us affectively and emotionally, memes reduce and simplify political facts and arguments. They are 'another move away' from rational, communicative debate, 'part of a new politics of affectivity, identification, emotion and humour' (Merrin 2019: 222). This paper reveals how memes communicate to us on these affective and emotional levels.

\section{Authoritarianism and Trump}

In mainstream media, Trump has been criticised for being too authoritarian by some, whilst being praised for being a 'strong man' by others. Authoritarianism consists of three core components which are (1) 'security against risks of instability and disorder', (2) 'group conformity to preserve conventional traditions and guard our way of life' and (3) 'loyal obedience toward strong leaders who protect the group and its customs' (Norris \& Inglehart 2019: 7). It is directly linked to the 'politics of fear' (see also Ozyumenko \& Larina 2021, this issue) where there is a search for collective security of a dominant group, usually referred to as 'our people' against 'them', at the expense of personal freedoms. Our people can be defined in terms of nationality and citizenship, or more locally as in-groups based 
on race, religion, ethnicity, location, generation, party, gender, or sex (Zappettini $2019 ; 2021)$. In any of these forms, authoritarianism values group loyalty, shared cultural meanings and feelings of belonging (Norris \& Inglehart 2019: 7).

Authoritarianism becomes more dangerous when it is mixed with populism where populists 'pretend to speak for the underdog ['the people'] whose political identity is constructed by opposing it to an elite' (De Cleen \& Carpentier 2010: 180). However, dependent on context, who are defined as 'the people' and 'the elite' is fluid. Authoritarian-populist politicians tell us that in order to defend 'us' we need to restrict 'them'. This toxic combination results in policies that justify the restriction of immigrants, refugees, asylum seekers, and foreigners. At the time of writing, authoritarianism-populist politicians and parties had gained power in a number of states including the US, Austria, Italy, the Netherlands, Poland, Turkey and Switzerland. In other states, they hold sway, including UKIP and the Brexit Party in catalysing and influencing Brexit (Norris \& Inglehart 2019: i). Much praise and criticism about Trump in the media are in terms of authoritarianism. Though some mainstream media criticise Trump for being too authoritarian, some right-wing media celebrate this (Merrin 2019, Way 2021a).

Trump's style of governance may easily be considered authoritarian-populist as defined above. He 'uses populist rhetoric to legitimize his style of governance, while promoting authoritarian values that threaten the liberal norms underpinning American democracy' (Norris \& Inglehart 2019: 3). He and his supporters have attacked the 'the liberal press and their ideals of holding authority to account' (Happer, Hoskins \& Merrrin 2019: 15). All the while, he calls his opponents 'phoney' or 'dopey', labels media and journalists as 'corrupt' or 'fake news' while discourses of violence, racism and wider uncivility become the 'new' norms of social and political doing and acting (Krzyżanowski 2020: 4). He has become the darling of the alt-right in the US, defined as 'a range of extreme far-right movements and positions broadly unified by their rejection of traditional, mainstream Christian conservativism and republicanism in favour of white nationalism and supremacism' (Merrin 2019: 206).

\section{4Chan}

4Chan is one of a number of websites that have become platforms to communicate alt-right ideas (Happer, Hoskins \& Merrin 2019: 13). Set up by Christopher Poole in 2003, 4Chan consists of un-archived, subject-based boards with anonymous postings. It was 'part of the anything goes, libertarian culture of the internet, but its desire to shock and drift to the right would eventually make it and Reddit key sites for the alt-right' (Happer, Hoskins \& Merrin 2019: 13). It is ' $[t]$ he modern online home of trolling and the spirit of chaos... the must-see, cesspit of the internet: as Obi-Wan Kenobi says (in a quote often applied to the site): "You will never find a more wretched hive of scum and villainy" (Merrin 2019: 204). Here internet users experience 'gratuitous pornography, misogyny, racism, most forms of "phobia", graphic insults, general grossness and maximum 
offensiveness' (Merrin 2019: 204). Many of the memes that populate our mainstream social media feeds originate from 4Chan, it being 'one of the most creative corners of the web, with its chaos birthing almost every major meme or aspect of internet culture over the last decade' (Merrin 2019: 204).

4Chan is not only creative, but also political. It has run an attack campaign aimed at the Church of Scientology for attempting to censor content on the internet. It also aimed its rage at a woman game designer and then other feminist commentators in so-called 'Gamergate'. Here posters presented themselves as underdogs and victims, despite accusations of abuse by 'snowflakes, unicorns and cry bullies'. They pitted themselves against mainstream media and feminism, naming them as both 'impossibly strong' and 'laughably weak' (Lees 2016). Not long after this campaign, 4Chan turned its attention to Trump. At first, his candidacy was seen as a joke, but then it quickly evolved into support (Merrin 2019). Its support for Trump is not surprising, considering 'his politics closely chimed with [4Chan's] the outsider-culture, anti-PC sentiment, racism and misogyny and the claims of post-truth "shitposters" (Merrin 2019: 208). Links between 4Chan and Trump are more than just shared political views. Trump and his staff retweeted alt-right videos and images created on 4Chan and 4Chan's memes were part of Trump's campaign to relentlessly tilt sentiment on social media in his favour. As one former campaign official said: 'He clearly won the war against Hillary Clinton day after day after day' (Schreckinger 2017).

4Chan's /po/ board 'is by far the most influential disseminator of memes in terms of the raw number of memes originating from it. In particular, it is more influential in spreading racist and political memes' (De Cristofaro 2018). It delivers an important youth demographic to the alt-right, playing a central role in attacks on mainstream media, mainstream politics, the culture of political correctness and Left-wing identity politics. These attacks are evident on 4Chan and in Trump's 2016 election campaign. In fact, many memes that originate from 4Chan cross over into mainstream platforms such as Twitter and Facebook to appeal to 'normies'. It was instrumental in anti-Hillary Clinton campaigns such as Pizzagate and other conspiracy theories. All the same, 4Chan is also a thorn in Trump's side. Despite mainstream media criticising Trump, these actions have had little effect on his supporters, feeding into the narrative of Trump as an outsider. However, memes on 4Chan and other social media platforms have seen vehement responses by Trump and his supporters suggesting 'humour and satire: the same troll-culture that supports Trump and which he incarnates has become one of the most important weapons against him' (Merrin 2019: 213).

\section{Data}

Our study examines a sample of image-based memes of Trump taken from 4Chan's /po/ board in the spring of 2019. This time was chosen to reflect what was in digital circulation about half way through Trump's term in office. During this time, there were countless memes and images being created, manipulated and 
circulated in threads about Trump on 4Chan. This is not surprising, seeing its history of promoting not only Trump, but also the alt-right. This researcher scanned hundreds of feeds in order to understand how memes expressed ideas about Trump in terms of authoritarianism. Through this authoritarianism prism, four dominant themes about Trump emerge. These are: Trump is God-like, Trump is a powerful leader, Trump is powerful against the media and Trump is not being strong enough. In the following analysis, we closely analyse two representative memes from each of these categories to reveal how they articulate discourses of authoritarianism affectively and emotionally.

\section{Methodology}

Memes we examine are still images and some include written text. We offer a brief description of posters' comments about the memes we analyse to consider how they were 'read' by posters. We use Multimodal Critical Discourse Studies (MCDS) to analyse how lexica and images independently and together articulate discourses. This approach has the advantage of revealing the way each mode works to articulate discourses 'on a particular occasion, in a particular text' (Kress \& van Leeuwen 2001: 29; see also Ponton 2016). MCDS finds its origins in Critical Discourse Analysis and Halliday's (1994) functional grammar which assume linguistic and visual choices reveal broader discourses articulated in texts (Kress \& van Leeuwen 2001). MCDS draw out the details of how broader discourses are communicated and how the different modes play slightly different roles (Machin \& Mayr 2012). These discourses can be thought of as models of the world and project certain social values and ideas which contribute to the (re)production of social life. The aim of analysis is to reveal what kinds of social relations of power, inequalities and interests are perpetuated, generated or legitimated in texts both explicitly and implicitly (van Dijk 1993).

We examine how participants are represented in our sample texts, an approach used extensively in previous research and shown to be central to revealing discourses (Wodak et al. 1999, Bishop \& Jaworski 2003, Wodak \& Weiss 2005). Written lexica is analysed (when part of a meme) by leaning on van Leeuwen (1996 \& 1995) and Fairclough's (2003) seminal work on the representation of social actors. We consider participants in terms of how they are named and how their actions are represented. Here questions such as who does what to whom and how participants are represented in more active or passive roles are examined. Though originally applied to written texts, social actor analysis is also applied to images leaning on the influential work of Kress and van Leeuwen (1996 \& 2001) and Machin (2007). These scholars define three broad analytical categories for analysing the visual representation of social actors: Positioning, kinds of participants and actions. How viewers are symbolically positioned in relation to participants in images through gaze, angle of interaction and distance is considered. These choices have repercussions in terms of representations of power and connotations of engagement with viewers (Kress \& van Leeuwen 1996: 127-128). 
When examining the kinds of participants, we consider whether social actors are represented as individuals or groups, culturally and/ or biologically categorised and who is included and excluded. The representation of action, including process types and agency, carry with them discourses of power and are an integral part of our visual analysis.

Choices in how imagery is organised and composed is also analysed. Here, we consider the internal 'flow' or organisation of an image, salience and the degree of modality suggested in an image. Image organisation, including the positioning of elements and framing, contribute to an image's internal 'flow' and carry with it ideological meanings (Kress \& van Leeuwen 1996). Salience, which connotes importance and power, is expressed through visual devises such as potent cultural symbols, size, colour, tone, focus and foregrounding (Machin 2007). Modality is a literary concept associated with the amount of certainty a producer assigns to a text. In visuals, 'modality can be decreased or increased depending on how much the image departs from how we would have seen the image had we been there' (Machin 2007: 46). Not all of these visual elements are analysed for each meme, just like not all memes include written text. Instead, we use the above analytical tools based on their usefulness in revealing discourses about Trump, authoritarianism, emotion and affect.

\section{Analysis}

\subsection{Memes of God-like powers}

One obvious strategy used to represent Trump as powerful is producing a visual mash up with his head on a mythical character's body. 4Chan's God Emperor Trump series depicts Trump as ruler of the world, wearing the armour of the immortal character Emperor of Mankind (also known as 'God Emperor' or 'Imperium of Man') from the war game Warhammer 40,000. According to 'Know your meme' website, these images first appeared on 4Chan on 16 June 2015.

Figure one is typical of these God Emperor Trump memes that appeared during our research. Trump stands tall. He wears the armour of Emperor of Mankind, culturally categorising Trump as a super-being (Machin 2007). Both the vertical and horizontal angle of interactions suggest strength. The camera looks up to Trump connoting great power (Machin 2007). His body also faces the camera, though his face looks off to the side. This connotes that he is not here to engage with viewers in a demand image that connotes interaction between viewer and subject (Kress \& van Leeuwen 1996: 127-128). Instead, he is offered to his viewers, posing to be admired. Abousnnouga and Machin (2010: 144) examine war monuments and find that most of the subjects (soldiers) do not symbolically demand anything of their viewers, but look off to the horizon. This has the meaning potential 'of wanting the public to see the soldiers as part of a different world, one of the glory of God... metaphorically [looking] to the future and high ideals.' Here Trump gazes in a similar manner, looking thoughtful, full of high ideals, powerful and into the future. Facial expressions are stern and forceful, making clear he is in power. His head is 
small compared to the massive body in the montage. However, both head and body are salient connoting importance and power. His body is salient through its size. But the meme's message of Trump as powerful would be lost on his fans if his head was difficult to identify. Light, focus and colour make his head salient. Furthermore, it is in focus and importantly, the creator of the image has suggested other-worldliness by including what looks like a halo around Trump's head to guide our eyes towards him.

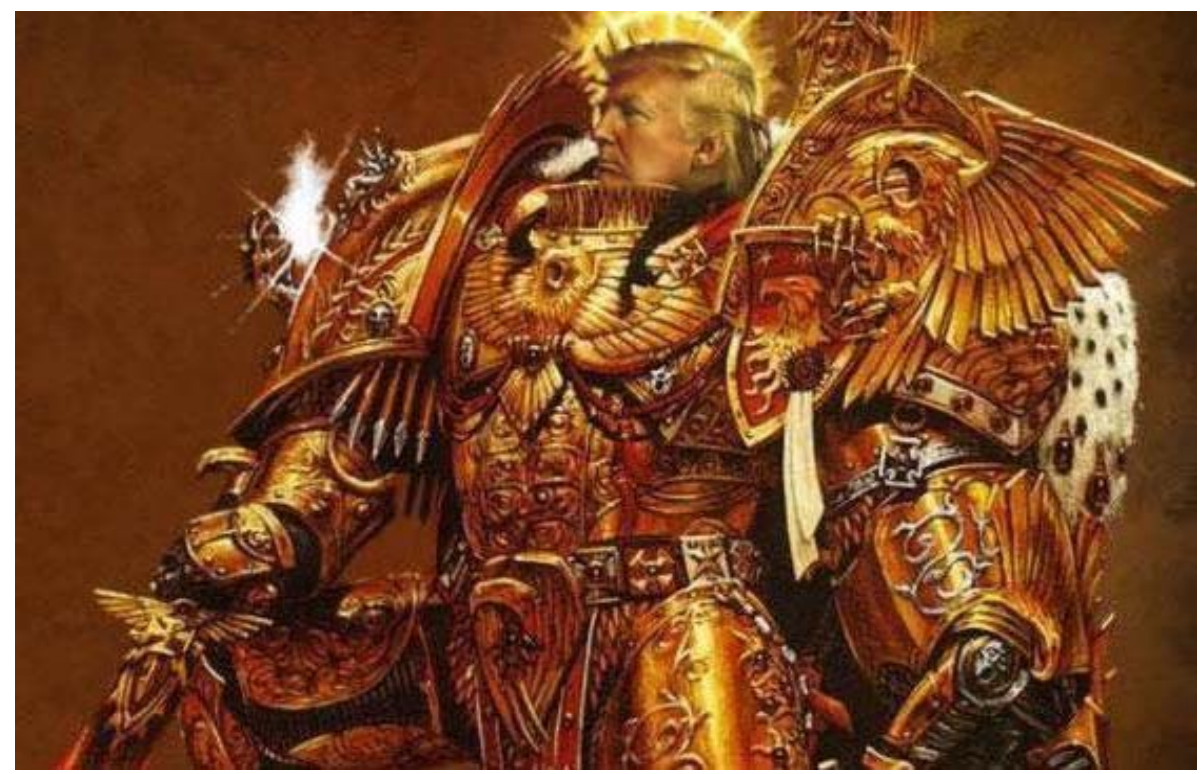

Figure 1. 'God Emperor Trump' image in pro-Trump 4Chan thread

Compositional choices also contribute to Trump's mythical status. There is no distinguishable background, just modular shades of golden-red. Here, Emperor God Trump is decontextualised. There is low modality in this image, where we do not know where Trump is or what he is doing. Modality markers, including the articulation of detail, background and depth, all contribute to how 'real' an image is perceived (Kress \& van Leeuwen 1996). Where figures are represented without a background, 'it usually means that the image is symbolic rather than documentary', symbolic rather than descriptive (Machin 2007: 51). Here, this contributes to the notion that this image is less about real power and Trump's actions and more about vague, emotive notions or fantasies of Trump's power experienced by his fans, however ill-defined these are (Machin 2007: 48).

The discourse of power, but not any real tangible power, is common throughout this series. In feeds with these memes, most posters express admiration for Trump and disdain for those who do not like him. Accompanying memes two, we see this in posts such as 'Dubs confirm Trump is God Emperor. Sorry Liberals' and 'That's God Emperor of Mankind Trump to you, you lowly worm'. In both these posts (and many others) we find an 'us' group of Trump fans, united in their admiration for Trump. 'Dubs' is a personal naming of one member of this group, active in confirming Trump's power. This presupposes that Dubs indeed has the 
authority to confirm, a positive representation of power. Distinct from this group is an 'other' group named using the pronoun 'you' above (elsewhere 'them'). This group is impersonally and generically named as 'Liberals' and evaluated negatively in 'you lowly worm'. By Dubs saying 'sorry' to Liberals for Trump's power, the writer presupposes Liberals are saddened by Trump's (great?) power.

Like the posts, the meme expresses admiration for Trump. Again, this is not about 'real' political power, like the power to cancel Obamacare, build a wall on the Mexican border, close the borders to Muslims or curtail criticisms in the press. This is symbolic power, confirming posters' admiration and pride towards Trump and Trump's America. Similarities between figures one and two include Trump's head mashed-up with the body of Emperor of Mankind. Both images see Trump's head small, yet salient through the use of colours, lighting and focus. Low modality through an indistinguishable background is also common, connoting both symbolic power over 'real' power and Trump as a mythical character.

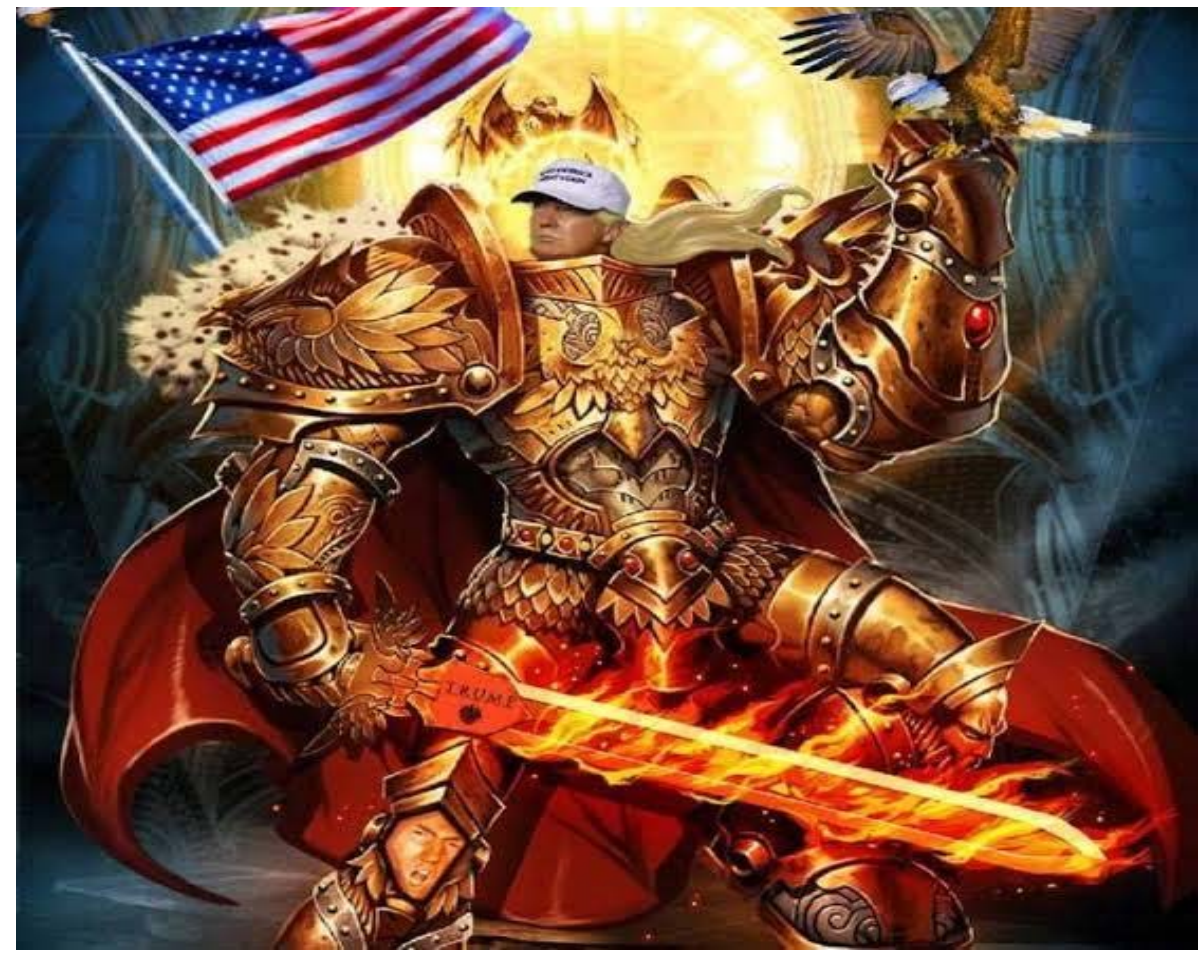

Figure 2. Symbolic power and nationalism in 'God Emperor Trump' images

Despite similarities, this meme is different than the first one we examined. Now potent cultural symbols change the discourse to one of nationalism and power. Salient are reminders of America that tap into fans' national pride. Most salient is the large American flag in focus. Also, an American bald eagle sits on Trump's left hand. This national symbol is not free to fly like the bird in the background of Trump's halo, but has been tamed, suggesting it has submitted to Trump's power. The America being promoted here is Trump's America. On the right knee of his armour is a face shot of Trump. He looks directly at viewers, demanding our 
attention and connoting power (Kress \& van Leeuwen 1996: 127-128). He is represented yelling suggesting aggression and power.

MAGA hats sit on top of Trump's and the bald eagle's heads. This cultural ornamentation is recognisable worldwide. MAGA, short for 'Make America Great Again', has become synonymous with a world view associated with Trump that includes controversial perspectives on race, immigration, the environment, politicians, authoritarianism and even knowledge (Makovicky, Tremon, \& Zanonai 2019). Part of this outlook is branding Trump as an unconventional, aggressive politician, symbolised here by the flaming sword with 'Trump' written on the handle. This image is not just about America, but about a style of leadership that is unconventional, authoritarian and populist. Though imagery such as this connotes great power and suggests authoritarianism, discourses admired by many 4Chan users and expressed in their comments, power is not 'real' or defined. As such, these memes affectively reflect and echo dominant discourses on 4Chan, discourses that celebrate Trump's America, his power and authoritarianism.

\subsection{Trump as powerful president/presidential candidate}

Trump's power is not just represented in God-like imagery in our sample. There are more descriptive representations of Trump's power, such as being a powerful president and presidential candidate. Figure three is an example used in a thread in June 2019. The feed is made up of insults and bantering amongst users about the merits of Trump and his supporters. This image accompanies a post that claims 'Losers lose their shit over how awesome this guy is'. Here we see Trump critics named as 'losers' and acting negatively by 'los[ing] their shit'. This very negative representation is opposed to this 'awesome ... guy', lexical choices that not only praise ('awesome'), but also suggest closeness and being one of 'us' by using the friendly colloquial term 'guy'.

Figure three, again we find discourses of power. This is a close up head shot, giving viewers a point of identification and making it easy for them to symbolically interact with Trump (Machin 2007). He looks straight at the camera, directly addressing viewers and suggesting power (Kress \& van Leeuwen 1996: 127-128). A slight smile on his face suggests confidence. Smiles can take on a variety of meanings depending on context and in some cases 'there may be a kind of smile that invites us in or allows us to share the joy of a moment' (Machin 2007:111). Here, Trump's smile indicates he wants us to be happy with him, to share in his victory. This is emphasised by the pronoun 'we' instead of ' $I$ ' in the accompanying written text. Groups constructed using 'we' in political discourse are constantly shifting and vague, referring to party, nation, government, residents or other combinations used to serve politicians' purposes (Fairclough 1989: 148). Here, 'we' is not defined, it possibly meaning Trump and his Republican party, conservatives, or even the alt-right. However, what is connoted is Trump is powerful, being central to a winning group of 'we' Trump supporters.

Though there is no action represented in the image, Trump is represented strong through cultural categorisation. His suit, white shirt and tie tell us this is a 
formal occasion and he is someone to be respected. The colours of the accompanying writing and surrounding boxes mirror those of the American flag suggesting a national event. What has been 'won' is not indicated in the thread or image, though it is likely the meme originally referred to Trump's election in 2016. In any circumstance, this is an empowering image. But like the images in the previous section, this is more symbolic than real. The background, again, gives no clues as to any particular event or issue. The image and context connote no real action and agency. Trump is not represented doing anything to anybody. However, this meme is about his power and 'us' being a part of this, though nothing is defined or quantifiable.

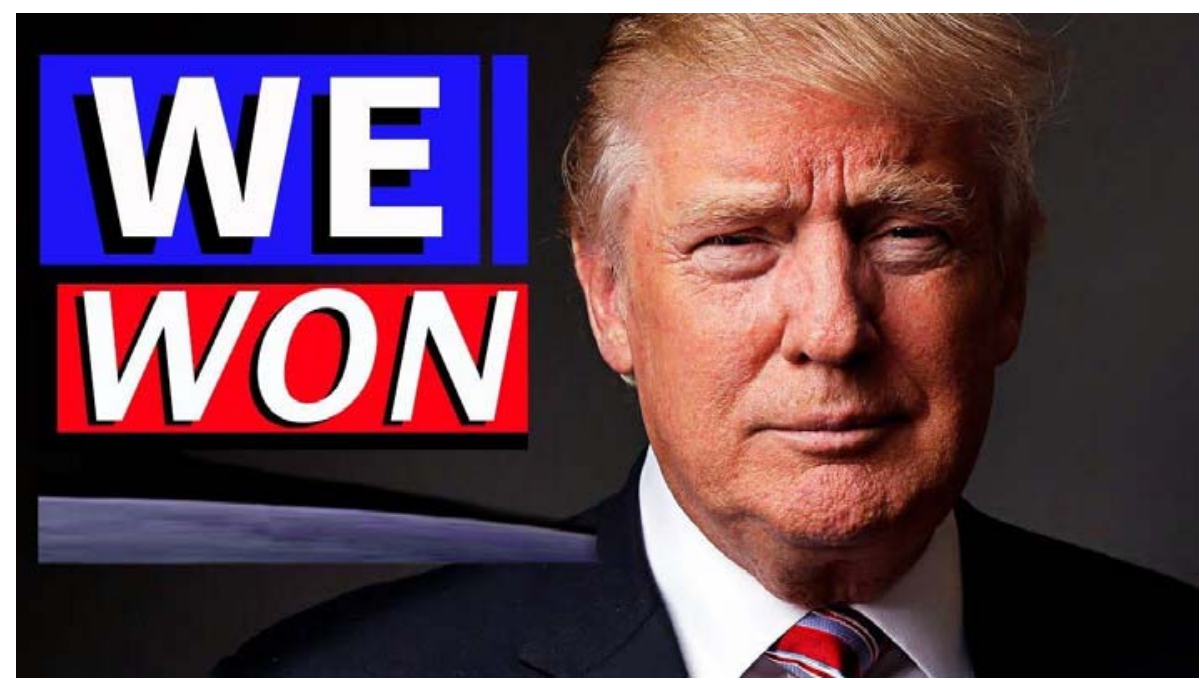

Figure 3. Descriptive representations of Trump's power in 4Chan memes

Trump supporters started the slogan 'Can't Stump the Trump' during his campaign to become the Republican presidential candidate. A Trump supporter first posted the slogan on 4Chan on 15 June 2015. A number of conservative media outlets repeated the phrase and Trump tweeted it on 13 October 2015. The now famous meme that incorporates this slogan (Fig. 4) appears regularly on 4Chan. The slogan implies an oppositional 'you' while the parochial lexical choice of 'stump' suggests informality. As such, Trump's unorthodox populist and confrontational style of politicking is connoted alongside his intellectual prowess. However, with no details or context represented in the slogan, this communicates to its audiences symbolically and affectively rather than in a tangible, descriptive manner.

Choices in the image further articulates discourses of Trump as a powerful leader of America. As is the case with the previous meme, Trump is salient connoting his importance. Aside from written text, excluded are any details of where he is and what he is doing. This is all about Trump. Unlike any of the previous images, there is no background here further suggesting the image is more symbolic than descriptive (Machin 2007: 34). Trump's head has low modality. That is, 'the image departs from how we would have seen the image had we been there' 
(Machin 2007: 46). Facial details, such as wrinkles, blemishes and faults are not present. There is a visual effect applied to the image that eliminates these realities and offers us a young, unreal version of Trump's head. Choosing a youthful-looking version of Trump has more associations with strength than that of an old, overweight man. Power is also connoted by Trump staring at viewers in a demand image, directly addressing his fans. His eyes are wide open as though he is afraid of nothing. His forehead slightly leans forward and his chin is tucked in as though he is daring viewers to question his intelligence asserted in the slogan. As seen in the last meme, there is a slight smile, connoting confidence.

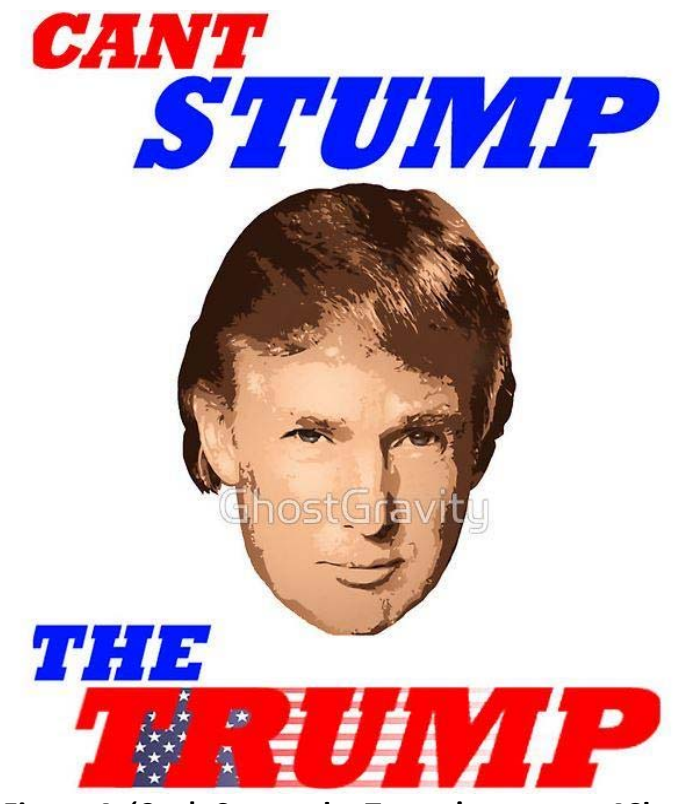

Figure 4. 'Can't Stump the Trump' meme on 4Chan

Kress and van Leeuwen (1996: 193) claim that the position of elements in images create 'compositional structures' which have meaning potential. One structure is the 'Triptych' where one element is centrally placed, acting as a mediator between other elements. Within this meme, Trump occupies the middle of the meme surrounded by colours of the American flag. He is literally at the centre of America. This discourse of Trump being an essential part of American nationalism is further articulated in how Trump's name is presented in the meme. His name is integrated with the US flag connoting a natural connection between the two (Machin 2007: 154). In fact, by having Trump's name on top of the flag, overlapping occurs again connoting Trump's strength and importance in America (Eisner 1985). Kress and van Leeuwen (1996: 193) also identify the top of compositions as the 'ideal', generalisation or simplification of an image. The bottom is the 'real', factual and grounded in the everyday that adds weight and credibility to the ideal. Here, the ideal is 'can't stump' while 'the Trump' is the factual that adds weight to the ideal. This construction emphasises Trump as 
unstoppable and clever in the context of power in America. As such, this appeals to posters' emotions of being proud to be a part of Trump's America. What this is missing is any details and specifics about exactly what is this power, who it effects and how.

\subsection{Images of Trump's relations with mainstream media}

Trump's relations with mainstream media are combative at best, well documented and discussed extensively in academia (see Hopper, Hoskin \& Merrin 2019). He makes no secret of his dislike for critical media, these being regular targets for his angst in his political rallies and press conferences. This tendency to attack critical mainstream media is aligned with authoritarian notions of loyal obedience toward a strong leader. Trump also shares his critical views on Twitter, including a GIF in 2017 of him body slamming the CNN logo. This GIF resulted in a meme campaign instigated by 4Chan on 5 July 2017 named 'Operation Autism Storm' or the 'Great CNN Meme War'. The campaign urged users to engage in a meme war with $\mathrm{CNN}$ because the network threatened to reveal the identity of the producer of this controversial GIF. 4Chan and Reddit users began spreading antiCNN images, videos and animated GIFs, including a contest for the best meme in the 'Great CNN Meme War'. A compilation of these memes, clips and GIFs subsequently appeared on YouTube. Much of this imagery is recycled and appears in feeds on 4Chan.

In this section we examine two memes that originate from the meme war. Posters' comments that accompany the memes, such as 'CNN is the fakest news of them all' and 'Destroy CNN by any memes possible', echo Trump sentiments of anger, and frustration at mainstream media. In both memes, Trump is salient. His head, which is mashed on to other characters, is large, light in colour and is in the foreground of the images. Unlike memes and images we have analysed thus far, here Trump is represented acting with agency connoting great power (Fairclough 1995: 113). The origins of figure five is the game Mortal Kombat. As is the case with all memes, knowledge of original media contribute to the meanings articulated in memes. This image is part of a fatality sequence in Mortal Kombat in which a character called Liu Kang (Trump here) turns into a dragon and eats the top half of his opponent. In the altered image, the Trump dragon dominates. He is much larger than the CNN character and in the centre of the image, a salient position. His body is puffed out in a posture that connotes a threat to the $\mathrm{CNN}$ character. The horizontal angle of interaction does not allow us to have any symbolic interaction with Trump. This image is offered to us as information available for scrutiny (Kress \& van Leeuwen 1996: 124). We are here to observe his strength. Trump's mouth is open, yelling, threatening and possibly ready to eat his opponent (CNN). His eyed glare down at $\mathrm{CNN}$, again emphasising his anger and power. CNN leans back, cowering under his threats. Here representations of power are clear. Represented actions of yelling, threatening and attacking are an emotional metaphor for Trump's actions and relations with mainstream media. 


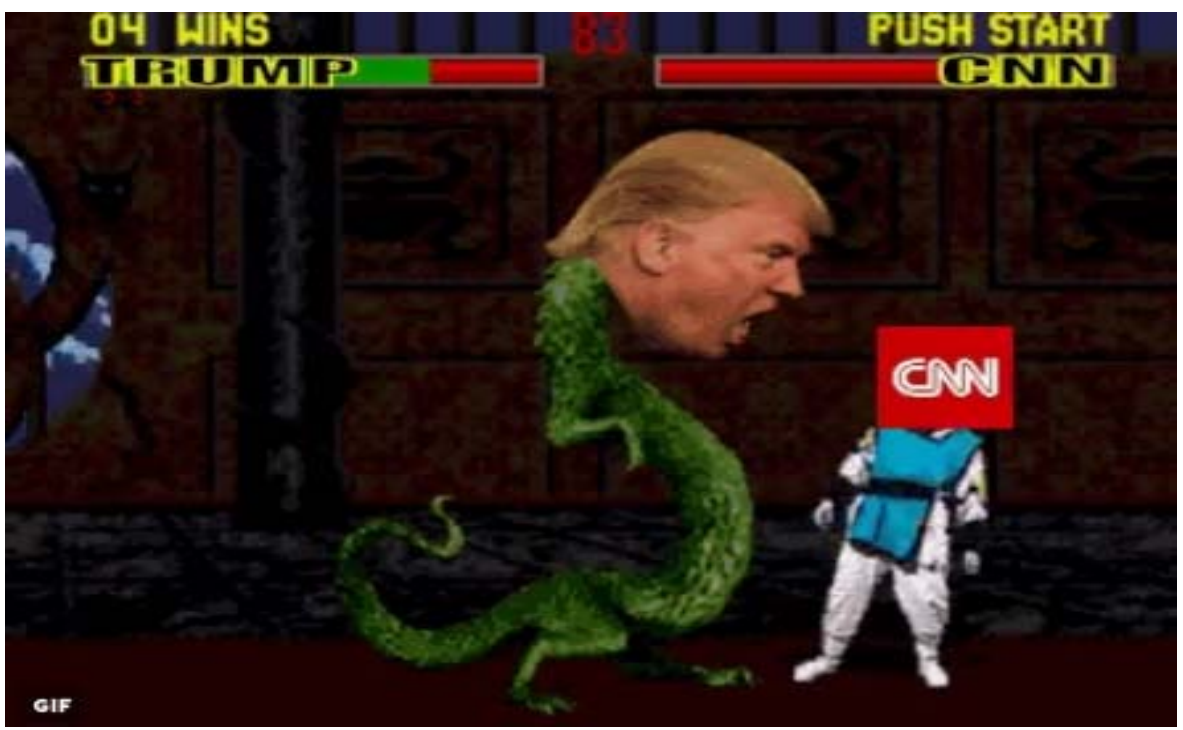

Figure 5. Meme of Trump as Liu Kang from the Mortal Combat game

In figure six, Trump again dominates the image. Here, his head is mashed on to the Hulk from The Avengers film (2012). In this image, Trump faces us, allowing viewers to witness his anger. The vertical angle of interaction emphasises his strength. In the original film, the Hulk fights Loki, a villain. Here Trump's head is mashed on to the superhero's body as he holds the villain by the feet in a sequence that sees the Hulk physically brutalise Loki. It is a one-sided fight due to the Hulk's enormous strength. Here, the superhero Trump physically brutalises CNN. This show of strength and connotations of who is right and who is wrong would not be lost on viewers, confirming their beliefs that mainstream media are wrong, it being 'fake news'. All the while, the meme offers no evidence or context for such assertions, just metaphoric over literal representations of actions that emphasise power and anger.

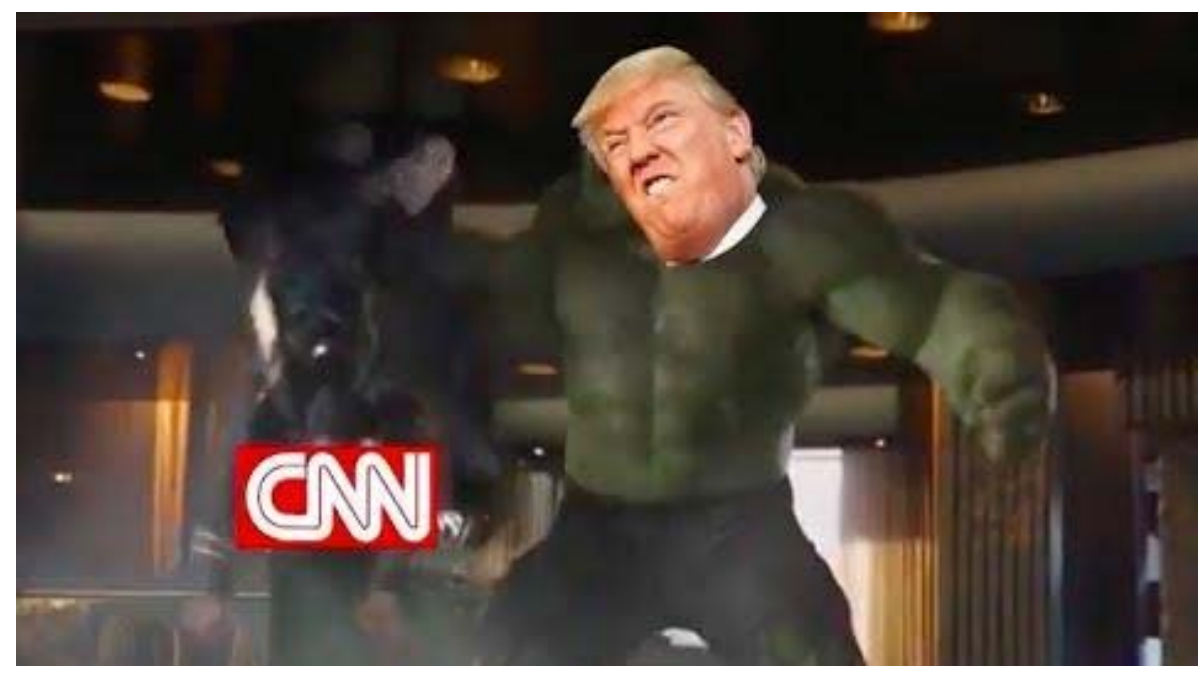

Figure 6. Trump as the Hulk from The Avengers film (2012) 


\subsection{Criticisms of Trump for not being strong enough}

There is a lot of criticisms of Trump in mainstream media and digital popular culture. Criticism is aimed at a large number of issues including his authoritarian tendencies, his (un)lawful actions, his style of governing and even his policies. Mostly, these come from a position that may be considered more liberal than Trump. However, in our search of 4Chan in 2019, there was a lot of criticism of Trump from the right. He is represented as not authoritarian enough and too tolerant towards minorities such as the Gay community, asylum seekers, Jewish people and Israel. In this section, we examine a two-image meme to reveal some of the strategies used to affectively connote praise and criticism about Trump's power.

As noted above, viewers of 4Chan inevitably engage with racist texts, whether viewing, posting, commenting or creating these (Merrin 2019: 204). This is evident in threads that defend and criticise Trump. One common theme during our sample time was an anti-Semitic discourse. Accompanying figure seven, we find the media is 'Jewish controlled' while YouTube is named 'Jewtube' and Facebook 'Faceberg'. These namings accompany an array of conspiracy theories where Jewish people are to blame for a whole host of injustices. In the thread that accompanies figure seven, we find some users attack Trump and some defend him. Trump is attacked as being weak, represented as following Israel in 'Trump is blind and Netanyahu is guiding him' and 'Make these shill memes that show him MIGA instead of MAGA.' We can only assume MIGA is an acronym that exchanges 'America' for 'Israel' in Trump's 'Make America Great Again' slogan. Elsewhere in the thread, the 'Jewish controlled media' are attacked for being against Trump who will 'destroy groping Joe [Biden] in 2020', while some users believe this thread is part of a Jewish-led conspiracy to turn voters against Trump. These comments express fear of the other, in this case Jewish people and Isreal, as well as anger at Trump for being too accommodating towards Isreal. These emotions are also represented in this meme.

The meme is in the style of a before and after sequence. Scholars tell us an image can be organised from left to right where the left can represent the old while the right can represent the new and the possible (Halliday 1994: 277). In this composition, the left is the past, something we already know, while the right is something new. In the left image, we see Trump culturally categorised as a Crusader. In popular fiction, the red on white cross we see on Trump's shield and chest plate is associated with not only the English flag, but also the Crusades and Saint George, England's 'patron saint'. Though not a symbol of America, this image resonates with Trump's policies towards Muslims, keeping in mind the eight Crusader wars were 'a series of religious wars between Christians and Muslims started primarily to secure control of holy sites considered sacred by both groups' ('Crusades' 2019). The background, though low in modality, depicts a dry, desertlike landscape, a large sun and a building with a dome roof. All these lean on stereotypes that suggest Trump is in the Middle East and most probably Isreal. 


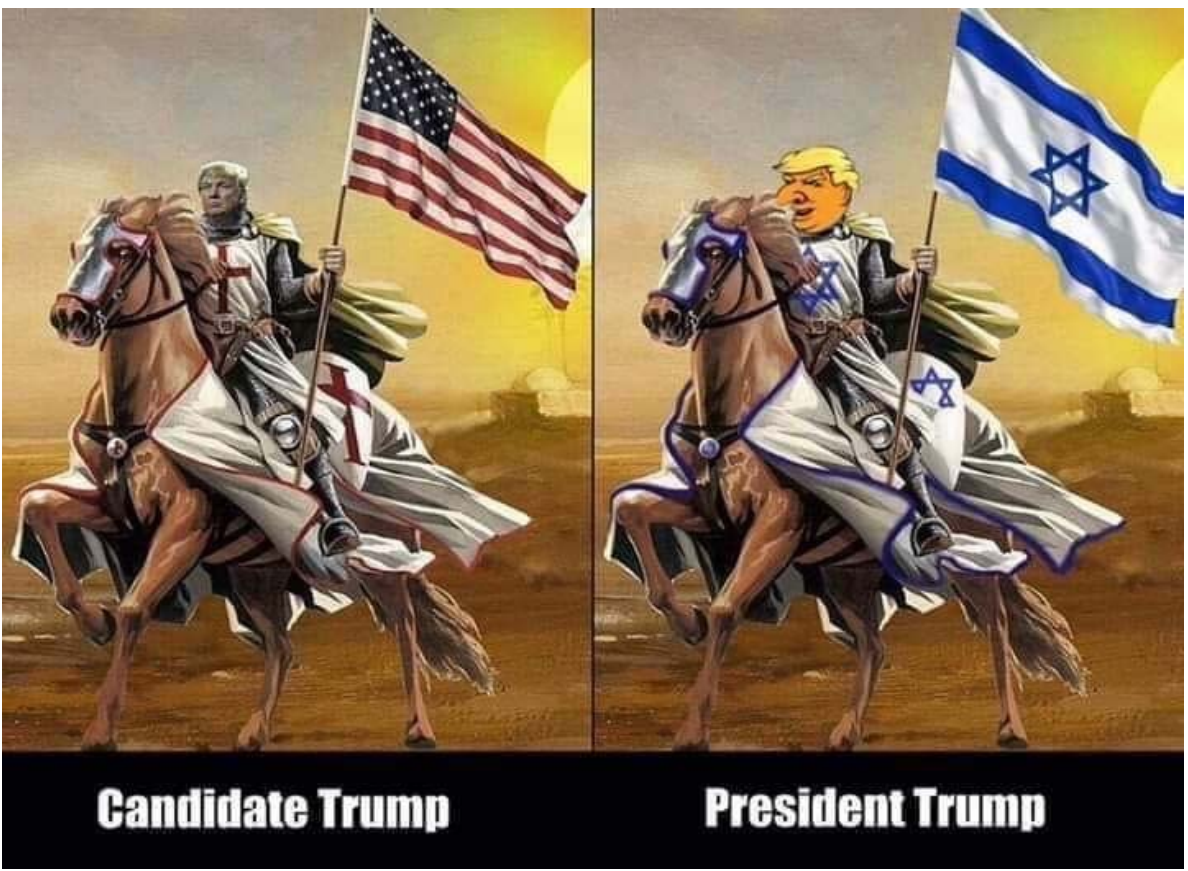

Figure 7. An anti-Semitic far-right meme critical of Trump on 4Chan

On the left, Trump is salient, with his head mashed on to a knight. But his head is not as salient as in previous memes that used lighting, colour, focus and/or size for salience. Here his head is distinguishable, but small. The horse and American flag are far more salient, the flag being both large and a potent cultural symbol. Like the positive images examined above, Trump is looking to the horizon - a man with a vision. This image connotes positivity, though not as obvious as previous examples. It provokes longing for a time when Trump had a vision as a candidate. His facial expressions, though difficult to distinguish, are stern and serious, like a crusader, off to make America Great Again.

The right-hand image has less certainty and positivity and lower modality than the left image. A 'realistic' photograph of Trump's head on the left is replaced with a caricature of Trump. It is biologically categorised based on racist stereotypes. He now has a large nose, squinting eyes and big eyebrows. Some of these qualities are used in Jewish hate literature. He looks untrustworthy connoted by his gaze that no longer looks to the horizon, but off to the side. He is now a flag bearer for Israel not America, indicated by the flag changes. What is connoted here is he now works in the national interest of Israel, playing on fears of betrayal by Trump fans. This is nothing short of treasonous behaviour for a president. He no longer is a warrior crusader fighting for America and its interests. Instead, he is a traitor, fighting for Israel and Jewish people. Though these criticisms are powerful, they are not specific. There is no articulation of an argument in the meme or in the thread of what Trump has done for or against America and/ or Israel. Though these memes may stir up emotional nationalist and racist feelings in 4Chan users, their lack of direct criticism is stark. 


\section{Conclusion}

In this paper, we have considered how image-based memes about Donald Trump's power shared on social media articulate political discourses. Whether pro or anti-Trump, the power represented is not about any real tangible power or actions, but symbolic and/ or metaphoric. We find memes lean on emotional discourses about nationalism, racism and authoritarianism. Criticism and praise is not communicated through logical, clearly articulated, tangible arguments but affectively and emotionally. 4Chan users are presented with memes that manipulate images and lexica (sometimes) to communicate to us affectively, drawing on feelings and stereotypes that connote other-worldly strength and power. These lean on discourses of authoritarianism, discourses close to many 4Chan audience members.

Though these lean on emotion and affect, memes like these are important. They are pervasive, popular and effective. Many memes originate from the alt-right and seep into mainstream social media platforms such as Twitter, Facebook and YouTube. Here, they are viewed, considered, commented upon and shared by millions, social media being a primary source of entertainment and information for many of us. These activities get audiences to consider politicians and their actions. For example, the Israel meme analysed above suggests that Trump said one thing as a candidate but acted differently as a president. This message has the potential to stir anger in users and be part of a decision making process on how to vote. However, we should not over-stress their importance in terms of democratic ideals. Unlike mainstream media, these offer little room for their viewers to analyse and question issues, events and people, confirming rather than challenging already-held beliefs. Their affective, comical and simplified nature do not invite us to consider a range of views on pertinent issues in order for us to make informed political decisions. Instead, memes are a part of 'scroll culture' that metaphorically shouts emotionally-laden viewpoints at us. This does little in terms of creating an informed public as envisioned by Habermas (1991), thereby adding a further blow to an essential component of a healthy functioning democracy.

(C) Lyndon C.S. Way, 2021

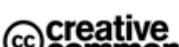
@cceative

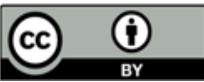

This work is licensed under a Creative Commons Attribution 4.0 International License https://creativecommons.org/licenses/by/4.0/

\section{REFERENCES}

Abousnnouga, Gill \& David Machin. 2010. Analyzing the language of war monuments. Visual Communication 9 (2). 131-149.

Allbeson, Tom \& Allan Stuart. 2019. The War of Images in the Age of Trump. In Catherine Happer, Andrew Hoskins \& William Merrin (eds.), Trump's Media War, 69-84. Switzerland, PalgraveMacmillan. 
Bishop, Jonathan. 2013. The effect of de-individuation of the internet Troller on Criminal procedure implementation: An interview with a Hater. International Journal of Cyber Criminology 7 (1). 28-48.

Bishop, Hywel \& Adam Jaworski. 2003. We beat 'em: nationalism and the hegemony of homogeneity in the British press reportage of Germany versus England during Euro 2000. Discourse and Society 14 (3). 243-271.

Boyd, Danah. 2008. Can social media sites enable political action? International Journal of Media and Cultural Politics 4 (2). 241-244.

Clottes, Jean. 2019. Cave Art. Encyclopeadia Britannica. https://www.britannica.com/art/ cave-painting (accessed: 17 July 2020).

'Crusades'. 2019. History. https://www.history.com/topics/middle-ages/crusades (accessed: 15 June 2020).

Dawkins, Richard. 1976. The Selfish Gene. Oxford: Oxford University Press.

De Cleen, Benjamin \& Nico Carpentier. 2010. Contesting the populist claim on "the People" through popular culture: The 0110 concerts versus the Vlaams Belang. Social Semiotics 20 (2). 175-196.

De Cristofaro, Emiliano. 2018. Memes are taking the alt-right's message of hate mainstream. Information Security Research and Education. University College London: Bentham's Gaze. https://www.benthamsgaze.org/2018/12/13/memes-are-taking-the-alt-rights-messageof-hate-mainstream/ (accessed: 21 April 2019).

Denisova, Anastasia. 2019. Internet Memes and Society: Social, Cultural, and Political Contexts. New York \& London: Routledge.

Esralew, Sarah \& Danah Young. 2012. The influence of parodies on mental models: Exploring the Tina Fey-Sarah Palin phenomenon. Communication Quarterly 60 (3). 338-352.

Fairclough, Norman. 1989. Language and Power. Harlow: Pearson Education.

Fairclough, Norman. 1995. Media Discourse. London: Edward Arnold.

Fairclough, Norman. 2003. Analyzing Discourse: Textual analysis for Social Research. London: Routledge.

Habermas, Jurgen. 1991. The public sphere. In Chandra Mukerji \& Michael Schudson (eds), Rethinking popular culture. Contemporary perspectives in cultural studies, 398-404. Berkeley/Los Angeles: University of California Press.

Halliday, M.A.K. 1994. An Introduction to Functional Grammar (second edn). London: Edward Arnold.

Happer, Catherine, Andrew Hoskins \& William Merrin. 2019. Weaponising reality: An introduction to Trump's war on the media. In Catherine Happer, Andrew Hoskins \& William Merrin (eds), Trump's Media War, 3-22. Switzerland, PalgraveMacmillan.

Kress, Gunther \& Theo van Leeuwen. 1996. Reading Images: The grammar of visual design. Oxon: Routledge.

Kress, Gunther \& Theo van Leeuwen. 2001. Multi-modal discourse: The Modes and media of Contemporary Communication. London: Arnold.

Krzyżanowski, Michal. 2020. Normalization and the Discursive Construction of 'New' Norms and 'New' Normality: Discourse in/and the Paradoxes of Populism and Neoliberalism. Social Semiotics 30 (4). 431-448.

Lavoie, Stephane. 2018. Modern photography is changing how we remember our lives. OneZero. https://onezero.medium.com/modern-photography-is-changing-how-weremember-our-lives-4b59adab4a2e (accessed: 21 April 2019).

Lees, Matt. 2016. What Gamergate should have taught us about the 'alt-right'. The Guardian. https://www.theguardian.com/technology/2016/dec/01/gamergate-alt-right-hate-trump (accessed: March 2017). 
Machin, David. 2007. Introduction To Multimodal Analysis. London: Hodder Education.

Machin, David. 2013. What Is Multimodal Critical Discourse Studies? Critical Discourse Studies 10 (4). 347-355.

Machin, David \& Andrea Mayr. 2012. How to do Critical Discourse Analysis: A Multimodal Introduction. London: Sage.

Merrin, William. 2019. President Troll: Trump, 4Chan and Memetic Warfare. In Catherine Happer, Andrew Hoskins \& William Merrin (eds.), Trump's Media War, 201-226. Switzerland, PalgraveMacmillan.

Milner, Ryan. 2016. The World Made Meme: Public conversations and participatory Media. Cambridge: MIT Press.

Norris, Pippa \& Ronald Inglehart. 2019. Cultural Backlash: Trump, Brexit and Authoritarian Populism. Cambridge: CUP.

Ozyumenlo, Vladimir \& Tatiana Larina. 2021. Threat and fear: Pragmatic purposes of emotionalisation in media discourse. Russian Journal of Linguistics. Special issue: Emotionalisation of media discourse 25 (3). 746-766.

Papacharissi, Zizi. 2015. Affective publics and structures of storytelling: sentiment, events and mediality. Information, Communication and Society 19 (3). 307-324.

Phillips, Whitney. 2009. Why so socialist? Unmasking the joker. http://henryjenkins.org/blog/ 2009/08/unmasking_the_joker.html (accessed: 29 March 2018).

Ponton, Douglas. 2016. Movement and meaning: Towards an integrated approach to political discourse analysis. Russian Journal of Linguistics. Special issue: Discourse Analysis in the 21st Century: Theory anf Practice (I). 20 (4). 122-139.

Ponton, Douglas. 2021. Memes and how they mean: some pragmatic aspects of Covid-19 satire. Russian Journal of Linguistics. Special issue: Emotionalisation of media discourse. 25 (3).

Ponton M. Douglas. 2021. "Never in my life have I heard such a load of absolute nonsense. Wtf" Political satire on the handling of the COVID-19 crisis. Russian Journal of Linguistics 25 (3). 767-788.

Schreckinger, Ben. 2017. World War Meme: How a group of anonymous keyboard commandos conquered the internet for Donald Trump-and plans to deliver Europe to the far right. Politico Magazine. https://www.politico.com/magazine/story/2017/03/memes4chan-trump-supporters-trolls-internet-214856 (accessed: 2 April 2018).

Suler, John. 2005. The online Disinhibation Effect. International Journal of Applied Psychoanalytical Studies 2 (2). 184-188.

Way, Lyndon. 2021a. Analysing Politics and Protest in Digital Popular Culture: A multimodal approach. London: Sage.

Way, Lyndon. 2021b. Populism in musical mash ups: Recontextualising Brexit. Social Semiotics 31 (3).

Weyler, Rex. 2020. Remembering Bob Hunter: Mind bomber. Greenpeace. https:/www.greenpeace.org/international/story/30250/bob-hunter-greenpeace-foundermemorial-mindbombs-rex-weyler/ (accessed: 1 August 2020).

Wiggins, Bradley. 2019. The Discursive Power of memes in Digital Culture: Ideology, semiotics, and intertextuality. New York \& London: Routledge.

Wodak, Ruth, Rudolf de Cillia, Martin Reisigl \& Karin Leibhart. 1999. The discursive construction of national identity. Edinburgh: Edinburgh University Press.

Wodak, Ruth \& Gilbert Weiss. 2005. Analyzing European Union discourses: Theories and applications. In Ruth Wodak \& Paul Chilton (eds), A New Agenda in (Critical) Discourse Analysis: Theory, Methodology and Interdisciplinarity, 121-136. Amsterdam: John Benjamins. 
Zappettini, Franco 2019. European identities in discourse: a transnational citizens' perspective. London: Bloomsbury Advances in Critical Discourse Studies.

Zappettini, Franco. 2021. The tabloidization of the Brexit campaign: Power to the (British) people? Journal of Language and Politics 20 (2). 277-303.

\section{Article history:}

Received: 10 February 2021

Accepted: 12 June 2021

\section{История статьи:}

Дата поступления в редакцию: 10 февраля 2021

Дата принятия к печати: 12 июня 2021

\section{Bionote:}

Lyndon C.S. WAY is a communications and media lecturer at the University of Liverpool. His area of research is analysing relations between (digital) popular culture and politics through the lens of multimodal critical discourse studies. He has co-/edited a number of publications on music and digital popular culture as multimodal political discourse, written a monograph on Turkish music and politics (Bloomsbury 2018) and another entitled Analysing Politics and Protest in DigitalPopular Culture (Sage 2021).

\section{Contact information:}

University of Liverpool

Foundation Building, Brownlow Hill, Liverpool, L69 7ZX, UK

e-mail: lyndon.way@liverpool.ac.uk

ORCID: 0000-0002-0481-4891

\section{Информация об авторе:}

Линдон К.С. УЭЙ преподает теорию коммуникации и СМИ в Ливерпульском университете. Область его исследований - анализ отношений между (цифровой) популярной культурой и политикой через призму мультимодальных исследований критического дискурса. Он является редактором и соредактором ряда изданий о музыке и цифровой популярной культуре как мультимодальном политическом дискурсе, автором монографии о турецкой музыке и политике (Bloomsbury, 2018), a также монографии Analysing Politics and Protest in Digital Popular Culture («Анализируя политику и протест в цифровой популярной культуре») (Sage 2021).

\section{Контактная информация:}

University of Liverpool

Foundation Building, Brownlow Hill, Liverpool, L69 7ZX, UK

e-mail: lyndon.way@liverpool.ac.uk

ORCID: 0000-0002-0481-4891 